\title{
Capability and Technology Performance Goals for the Next Step in Affordable Human Exploration of Space
}

\author{
Diane L. Linne ${ }^{1}$ \\ NASA Glenn Research Center \\ Cleveland, $\mathrm{OH} 44135$ \\ Gerald B. Sanders ${ }^{2}$ \\ NASA Johnson Space Center \\ Houston, TX 77058 \\ and \\ Karen M. Taminger ${ }^{3}$ \\ NASA Langley Research Center \\ Hampton, VA 23681
}

The capability for living off the land, commonly called in-situ resource utilization, is finally gaining traction in space exploration architectures. Production of oxygen from the Martian atmosphere is called an enabling technology for human return from Mars, and a flight demonstration to be flown on the Mars 2020 robotic lander is in development. However, many of the individual components still require technical improvements, and system-level trades will be required to identify the best combination of technology options. Based largely on work performed for two recent roadmap activities, this paper defines the capability and technology requirements that will need to be achieved before this gamechanging capability can reach its full potential.

\section{Nomenclature}

$R W G S=$ reverse water gas shift

SOE $\quad=$ solid oxide electrolyzer/electrolysis

\section{Introduction}

$\mathbf{I}^{\mathrm{N}}$ $\mathrm{N}-S I T U$ resource utilization, massless exploration, living off the land, bootstrapping exploration: these phrases and many others have been used to name an exploration philosophy that espouses the basic tenet that we cannot afford to continue to explore space in the same manner as we do now - by launching everything we need out of the Earth's mighty gravity well. This exploration philosophy requires advances in technologies in a wide range of capabilities such as in-space manufacturing, robotics, autonomous operations, resource identification and acquisition, consumable production from in-situ resources, and many others. Two current NASA activities are working to identify and document the performance goals for a wide variety of space exploration capabilities. The Systems Maturation Teams, led by the NASA Human Exploration and Operations Mission Directorate, are tasked with identifying the broad range of capabilities that will be needed to expand human presence beyond low Earth orbit. The Technology Roadmap Teams, led by the NASA Office of Chief Technologist, are tasked with identifying the host of technology improvements that will be needed to achieve these capabilities.

This paper presents details on the capabilities and technologies needed to reduce dependency on Earth supplies. Performance goals are introduced and traced back to their origins. These goals are derived from recent experimental

\footnotetext{
${ }^{1}$ Senior Research Engineer, Propulsion Division, MS 301-3, AIAA Associate Fellow.

${ }^{2}$ Senior Aerospace Engineer, Propulsion and Power Division, EP3, AIAA Member.

${ }^{3}$ Senior Materials Research Engineer, Advanced Materials \& Processing Branch, MS 188A.
}

1

American Institute of Aeronautics and Astronautics 
work showing what is currently possible, analytical models showing what could be possible, and specific design reference missions defining what needs to be possible.

\section{Capability Requirements}

Capability is defined as the ability to do something. In the case of in-situ resource utilization, we want to be able to make useful stuff, such as propellants, life-support consumables, structures, equipment, etc., at the exploration site. Therefore, the first level of defining technology needs is to identify what we want to make, where we want to make it, and how much do we need.

\section{A. Lunar Missions}

A strategic goal for all mission architecture studies for human exploration of the moon after the release of the NASA Vision for Space Exploration in February 2004 has been to learn to use the resources of space to enable sustainable and affordable exploration. Since as early as 1961, scientists and engineers have considered, analyzed, and even tested techniques in the laboratory to extract oxygen and other potential resources (silicon and metals) from lunar regolith. However, since no process had ever been flown, lunar mission and architecture planners could not rely on the products obtained from space resources for early mission critical roles. Instead, ISRU systems and products were examined in ways that might enhance early missions until they were adequately proven. Studies during the NASA Constellation Program and the international Global Point of Departure (GPoD) ${ }^{1}$ were used to define both ISRU applications as well as potential production needs to help understand the mission benefits and to anchor development, test, and future mission integration activities. These studies identified four ISRU capabilities that could significantly enhance early missions while enabling long-term human lunar exploration: oxygen production for life support closure, oxygen production for crew ascent propulsion from the lunar surface, regolith excavation for habitat burial for radiation protection, and civil engineering (berms, landing pads, roads) for mitigation of landing plume and dust damage.

For oxygen production for life support closure, $1000 \mathrm{~kg}$ per year of oxygen for breathing air and another $800 \mathrm{~kg}$ of oxygen to make water could be needed to support a crew of 4 at a permanently crewed outpost on the lunar surface. An early design for a crewed ascent vehicle based on liquid oxygen/methane propellants required between $3000 \mathrm{~kg}$ to $3500 \mathrm{~kg}$ of oxygen for ascent to lunar orbit. Based on these studies, ISRU developers in the NASA Exploration Technology Development Program (ETDP) considered three stages of ISRU production requirements for oxygen: a demonstration stage of $250 \mathrm{~kg} / \mathrm{yr} \mathrm{O}_{2}$, leading to a pilot plant of 1 to $2 \mathrm{MT}$ of $\mathrm{O}_{2}$ per year for an early outpost, and finally a full scale plant of up to $10 \mathrm{MT}$ for crew and two ascent mission per year. ${ }^{2}$ Table I summarizes the lunar oxygen mission requirements for yearly oxygen needs, hourly oxygen production based on available sunlight for power, ${ }^{3}$ and total operational and cycle life.

All of the lunar mission architectures that were studied during the Constellation program required multiple crew and cargo vehicles landing at the same location on the moon. Because the Surveyor 3 lander showed possible signs of damage due to the dust entrained in the rocket engine plume of the Apollo 12 lander, Constellation mission planners became concerned about possible damage to already delivered hardware from the much higher thrust Altair lander. Three approaches to mitigate damage from dust entrained in landing rocket plumes were considered: 1) use terrain features to minimize or block the plume exhaust, 2) land more than $1 \mathrm{~km}$ away from previously landed vehicles/infrastructure, and 3) build landing pads/berms. Because option 1 is highly dependent on the landing location and option 2 could cause issues with movement and assembly of infrastructure, ISRU and mission planners considered what capabilities and requirements were needed for option 3, creating landing pads/berms. While the landing accuracy requirement for the Altair vehicle during Constellation was less than $100 \mathrm{~m},{ }^{4}$ accuracy after the initial landing was assumed to be beacon-aided and therefore estimated at $10 \mathrm{~m} \mathrm{3}$-sigma. ${ }^{5}$ Based on landing accuracy and plume/surface interaction models, it was determined that a $25 \mathrm{~m}$ diameter landing pad with a 1.5 to 3 meter berm placed between the landing pad and the infrastructure (one-half of the circumference) was satisfactory to mitigate the plume damage concern. Since missions to the lunar surface in the Constellation program were planned for every six months, the build rate for the landing pad and berm was the time between each mission.

Lunar regolith is a poor material for radiation shielding. Because solar radiation striking lunar regolith causes secondary radiation particles to be created, a regolith thickness of over one meter is required to mitigate both the primary and secondary radiation particles from reaching habitat/crew. How much excavation and regolith material movement was required to provide long-term radiation shielding for lunar mission studies was highly a function of whether the crew habitat could be deployed from the delivery lander and how quickly the shielding was required. In most cases, the excavation and regolith movement rates far exceeded those for oxygen extraction from regolith. Table I also summarizes the lunar regolith-moving requirements for construction and civil engineering.

2

American Institute of Aeronautics and Astronautics 
Table I. Oxygen production and construction/civil engineering capability goals for lunar missions.

\begin{tabular}{|c|c|c|c|}
\hline Capability Description & Capability Goal & Description/Basis & Refs. \\
\hline Oxygen Production & & & \\
\hline $\begin{array}{l}\text { Life support closure, } \mathrm{kg} / \mathrm{yr} \\
\text { Breathing air } \\
\text { Water }\end{array}$ & $\begin{array}{c}1,000 \\
800\end{array}$ & $\begin{array}{l}\text { crew of } 4 \text {; permanently crewed outpost } \\
\text { combine oxygen with scavenged hydrogen from descent tanks }\end{array}$ & \\
\hline $\begin{array}{l}\text { Crewed ascent, kg/flight } \\
\text { Flights per year }\end{array}$ & $\begin{array}{c}3,500 \\
2\end{array}$ & $\begin{array}{l}\text { oxygen/methane engine, OF - 3.5:1; ascent to lunar orbit } \\
\text { one mission every } 6 \text { months }\end{array}$ & \\
\hline $\begin{array}{l}\text { Total oxygen, } \mathrm{kg} / \mathrm{yr} \\
\text { Early outpost } \\
\text { Full scale }\end{array}$ & $\begin{array}{c}1,000 \\
10,000\end{array}$ & $\begin{array}{l}\text { life support breathing air closure only } \\
\text { two ascent missions plus life support }\end{array}$ & \\
\hline Available operational time & $70 \%$ & $\begin{array}{l}\text { solar power; outpost located near southern poles with up to } \\
90 \% \text { daylight }\end{array}$ & 3 \\
\hline $\begin{array}{l}\text { Production rate, } \mathrm{kg} / \mathrm{hr} \\
\text { Early outpost } \\
\text { Full scale }\end{array}$ & $\begin{array}{l}0.16 \\
1.63\end{array}$ & $\begin{array}{l}\text { life support closure only } \\
\text { two ascent missions plus life support }\end{array}$ & \\
\hline Operational life, days & 1095 & 3-year life before replacement & \\
\hline Cycle life, \# & 240 & $\begin{array}{l}\text { illumination/dark cycles vary between } 3 \text { and } 8 \text { per lunar day } \\
(\sim 28 \text { Earth days }) \text { at selected south polar sites; } 3 \text { year plant life }\end{array}$ & 3 \\
\hline Construction/Civil Engineering & & & \\
\hline $\begin{array}{l}\text { Landing pad, } \mathrm{kg} \\
\text { Time for production, days } \\
\text { Excavation rate, } \mathrm{kg} / \mathrm{hr}\end{array}$ & $\begin{array}{c}170,000 \\
180 \\
56\end{array}$ & $\begin{array}{l}25 \mathrm{~m} \text { diameter cleared to } 20 \mathrm{~cm} \text { depth; } 3 \text { meter semi-circular } \\
\text { berm at outer edge } \\
\text { one pad every } 6 \text { months } \\
\text { excavation during daylight hours }\end{array}$ & 4,5 \\
\hline $\begin{array}{l}\text { Habitat shielding, } \mathrm{kg} \text { / habitat } \\
\text { Time to cover hab, days } \\
\text { Excavation rate, } \mathrm{kg} / \mathrm{hr}\end{array}$ & $\begin{array}{c}180 \\
27\end{array}$ & $\begin{array}{l}4 \mathrm{~m} \text { deep x } 4 \mathrm{~m} \text { wide (half-circular) x } 6 \mathrm{~m} \text { long trench plus exit } \\
\text { ramp; } 1 \mathrm{~m} \text { backfill covering hab } \\
\text { Deliver and bury hab one mission before crew arrives } \\
\text { excavation during daylight hours }\end{array}$ & \\
\hline
\end{tabular}

Since the Lunar Crater Observation and Sensing Satellite (LCROSS) impacted in the Cabeus crater near the south pole and confirmed the presence of water ice of $5.6 \pm 2.9$ percent by mass, ${ }^{6}$ there has been significant interest by NASA and international space agencies on locating, measuring, and potentially mining polar water and other volatiles that may be present. Because these volatiles may exist in permanent or semi-permanent shadowed areas and subsurface temperatures need to be less than $100 \mathrm{~K}$ for stable ice retention, hardware for prospecting and mining must be able to survive temperatures from 100 down to $20 \mathrm{~K}$. Because the primary instrument to detect hydrogen, the neutron spectrometer, can only measure about $1 \mathrm{~m}$ below the surface and the energy and difficulty of mining water increases with depth, most mission concepts for prospecting and mining polar volatiles assume the resource will be within the top 1 to 2 meters of regolith.

Beyond the production of consumables for life support and generation of power and propellants, a sustainable human lunar presence will require a degree of self-sufficiency greater than any previously encountered in human space-missions. Furthermore, the flexibility to respond decisively to problems and hardware failures is a crucial issue for lunar habitation with implications to operational concepts and system hardware designs. In particular, a capability to repair wear and mechanical failures that occur due to the highly-abrasive lunar dust incursion will need to be developed. Manufacturing techniques such as additive manufacturing and machining are potential capabilities that will enable fabrication and repair of mechanical and structural components that will enhance supportability of long duration missions on the lunar surface and beyond.

In-situ manufacturing may also help alleviate the ever-present and growing need for power. One concept study suggests that a small rover could be used to produce large areas of photovoltaic cells directly on the lunar surface by melting lunar regolith and embedding transmission wires. ${ }^{7}$ The vacuum environment on the moon assists with refining the regolith into silicon and is an advantage for reducing atmospheric interference with photovoltaic cell efficiency. The lunar proximity to the sun makes use of solar energy feasible, even at low efficiencies anticipated due to impurities in the production process. For example, Ref. 7 suggests that a small rover could utilize lunar materials and vacuum to manufacture in a year a solar array producing $180 \mathrm{~kW}$ of electrical power at a solar cell conversion efficiency of 5 percent. 


\section{B. Mars Missions}

Mars capability requirements are driven by crewed ascent and life support needs. The NASA Mars Design Reference Architecture 5.0 (DRA 5) contains the most recent detailed assessment of a human mission to Mars. For the first time, production of oxygen propellant for the ascent vehicle is included in the baseline mission and is called enabling for robust human exploration missions. ${ }^{8,9}$ To enable the human exploration of Mars, a production plant capable of producing $25,000 \mathrm{~kg}$ of oxygen from the Martian atmosphere will be sent to the surface one opportunity before the crew launch. ${ }^{8,10}$

To ease concerns over the reliance on in-situ produced propellants for the return trip, the mission scenario requires all propellant and life support oxygen to be generated and stored in the ascent vehicle and life support tanks before the crew launches. From DRA 5, the production plant and ascent vehicle launch in December of year 1 of the campaign, and arrive on the Mars surface in October of year 2. The crew launches in March of year 4, which is 17 months, or 510 days, after the production plant arrives. Subtracting 30 days for contingency, the production plant has 480 days to produce the $25,000 \mathrm{~kg}$ of oxygen. The mission plan specifies that nuclear surface power is available, thus allowing continuous production at $2.2 \mathrm{~kg}$ per hour to meet the mission requirements.

Cycle life and total operational life are two additional important criteria when defining capabilities. Minimum operational life for the production plant is from the time it begins operations on the surface until the crew departs for Earth. From Ref. 8, there are 510 days between delivery of the plant and crew launch, 182 day transit time for the crew, and 510 days surface stay, adding up to a maximum operational life of 1200 days. Because of the availability of nuclear surface power, the production plant is expected to operate continuously, with only occasional shutdowns to handle unexpected conditions. The human Mars mission capability requirements are summarized in Table II. Methane fuel requirements, based on an oxygen-to-fuel ratio of 3.5 to 1 by mass, are also included in the table as an enhancing capability. ${ }^{8}$

Table II. Oxygen production capability goals for Mars human and robotic sample return missions.

\begin{tabular}{|c|c|c|c|}
\hline Capability Description & $\begin{array}{l}\text { Capability } \\
\text { Goal }\end{array}$ & Description/Basis & Refs. \\
\hline \multicolumn{4}{|l|}{ Human Mission } \\
\hline \multicolumn{4}{|l|}{ Oxygen production } \\
\hline Total mass, kg & 25,000 & $22,985 \mathrm{~kg}$ for ascent propulsion; $1906 \mathrm{~kg}$ for life support & $\begin{array}{l}\text { Ref. } 9 \text {, chart } 30 \\
\text { Ref. } 10, \text { pg } 5 \text {, Table I }\end{array}$ \\
\hline Time for production, days & 480 & $\begin{array}{l}\text { ISRU plant arrives October, yr } 2 \\
\text { Crew departs Earth March, yr } 4 \text { (510 days after ISRU plant arrives) } \\
\text { Crew arrives Mars September, yr } 4 \text { (182 days after departing Earth) } \\
\text { Crew departs Mars February, yr } 6 \text { (510 days after arriving Mars) }\end{array}$ & $\begin{array}{l}\text { Ref. } 8, \text { page } 52, \text { fig. } \\
6-3\end{array}$ \\
\hline Daily operation, hrs & 24 & nuclear surface power & Ref. 8 \\
\hline $\begin{array}{l}\text { Production rate, } \mathrm{kg} / \mathrm{hr} \\
\text { Oxygen } \\
\text { Methane }\end{array}$ & $\begin{array}{c}2.2 \\
0.57\end{array}$ & $\begin{array}{l}\text { for propulsion and life support; } 2.0 \mathrm{~kg} / \mathrm{hr} \text { for propulsion only } \\
\text { oxygen-to-fuel mixture ratio }=3.5: 1\end{array}$ & \\
\hline Operational life, days & 1200 & $\begin{array}{l}\text { Time from start of ISRU plant operation to departure of crew }(510+ \\
182+510 \text { days })\end{array}$ & \\
\hline Cycle life, \# & 40 & Assumed average one shut-down per month for diagnostics & \\
\hline \multicolumn{4}{|l|}{ Mars Direct Sample Return } \\
\hline \multicolumn{4}{|l|}{ Oxygen production } \\
\hline Total mass, $\mathrm{kg}$ & 1525 & $\begin{array}{l}\text { average value from multiple references; returned sample between } 1 \text { - } \\
30 \mathrm{~kg} \text {; ascent vehicle } 1,2 \text {, or } 2.5 \text { stages; parking orbit or direct return }\end{array}$ & Refs. $14-18$ \\
\hline Time for production, days & 460 & Typical stay time for conjunction-class mission less $10 \%$ contingency & \\
\hline Daily operation, hrs & 8 & solar power & \\
\hline Production rate, $\mathrm{kg} / \mathrm{hr}$ & & & \\
\hline $\begin{array}{l}\text { Oxygen } \\
\text { Methane }\end{array}$ & $\begin{array}{l}0.41 \\
0.12\end{array}$ & oxygen-to-fuel mixture ratio $=3.5: 1$ & \\
\hline Operational life, days & 510 & Production time plus $10 \%$ contingency & \\
\hline Cycle life, \# & 510 & Solar power results in daily cycle & \\
\hline
\end{tabular}

While in-situ propellant production is not considered in the baseline for a Mars sample return mission, several studies have shown how it can enable a direct-return-to-Earth mission profile, thereby simplifying the mission and reducing the risk of returning samples to Earth. In the most recent formal sample return study, a third mission is required to place a separate Earth return vehicle in orbit and perform a high-risk autonomous orbit rendezvous to

4

American Institute of Aeronautics and Astronautics 
transfer the sample canister. ${ }^{11-13}$ A direct-return capability, therefore, would provide an opportunity for a critical demonstration of oxygen propellant production while saving the significant cost of a third Mars mission. Several direct sample return mission studies were reviewed with various mission parameter assumptions: 1 to $30 \mathrm{~kg}$ sample returned, ascent vehicle either 1, 2, or 2.5 stages, ascent to parking orbit vs. no parking orbit, and return capsules ranging from $6 \mathrm{~kg}$ to $50 \mathrm{~kg}$ or more. ${ }^{14-18}$ The average oxygen propellant required for these missions is $1522 \mathrm{~kg}$ (Table III).

Table III. Summary of oxygen requirement for Mars direct sample return mission.

\begin{tabular}{|c|c|c|c|c|c|c|}
\hline $\begin{array}{l}\text { Sample Size, } \\
\text { kg }\end{array}$ & $\begin{array}{c}\text { Total } \\
\text { Propellant, } \\
\text { kg }\end{array}$ & $\begin{array}{c}\text { Engine } \\
\text { Mixture } \\
\text { Ratio, O/F }\end{array}$ & $\begin{array}{l}\text { Total } \mathrm{O}_{2} \\
\quad \mathrm{~kg}\end{array}$ & $\begin{array}{l}\text { Total } \mathrm{CH}_{4}, \\
\text { kg }\end{array}$ & Notes & Ref. \\
\hline 5 & 1382 & 3.5 & 1075 & 307 & $21 / 2$ stages to Mars parking orbit, then TEI & \multirow{2}{*}{14} \\
\hline 1 & 3330 & 3.4 & 2573 & 757 & Single-stage ascent direct to Earth & \\
\hline 5 & 2801 & 4.0 & 2241 & 560 & Ascent to $200 \mathrm{~km}$ parking orbit, then TEI & 15 \\
\hline 0.5 & 277 & 3.5 & 215 & 62 & $\begin{array}{l}2 \text { stage direct to Earth; employed extremely light } \\
\text { sample return capsule of only } 6 \mathrm{~kg}\end{array}$ & 16 \\
\hline $25-30$ & 2450 & 4 & 1960 & 490 & single stage to Mars parking orbit, then TEI & 17 \\
\hline 0.5 & 1420 & 3 & 1065 & 355 & $\begin{array}{l}\text { ISRU first stage delivers Earth Return Vehicle } \\
\text { (storable propellant) to near Mars escape }\end{array}$ & 18 \\
\hline & & Average: & 1522 & 422 & & \\
\hline
\end{tabular}

For a typical conjunction class mission the surface stay time is 510 days. Reserving 10 percent of this time for contingency leaves 460 days for propellant production. Assuming solar power for the sample return mission ( 8 hours of full-power production per day), production of $0.41 \mathrm{~kg}$ of oxygen per hour will meet the mission requirements. Minimum operational life is set at the surface stay duration of 510 days. Because solar power is assumed for the sample return mission, the production plant will experience a daily start/stop cycle, resulting in a minimum cycle life of 510 cycles. The Mars sample return capability requirements are summarized in Table II.

As with lunar missions, dust from the Martian environment will induce wear and mechanical failures at rates higher than previously experienced. In addition, with the longer durations of the Mars missions, there will be many more opportunities for mechanical failures to occur that must be repaired. Additive manufacturing and in-space machining techniques developed and tested on the ISS and the moon will be critical for reducing the risk of human exploration of Mars.

\section{Asteroid Missions}

On April $15^{\text {th }}$, 2010, the US President announced that NASA's next bold human exploration mission would be to send astronauts to an asteroid by 2025. Since then two companies, Planetary Resources and Deep Space Industries, announced that they intend to pursue development of systems to locate, prospect, and eventually mine resources from asteroids in space. In 2012, the Keck Institute for Space Studies released a report on the feasibility of moving a Near Earth Asteroid (NEA) into the lunar vicinity for subsequent scientific evaluation and resource exploitation. ${ }^{19}$ The Keck study was followed by several NASA studies to examine both the retrieval of a NEA as well as crew based exploration of the returned NEA in a distant lunar retrograde orbit.

Unlike the minerals and geology on the moon or Mars, NEA material physical, mineral, and volatile compositions vary greatly from one to the next. There are three broad categories of asteroids: Stony, Stony-Iron, and Iron-Metal, that are further divided into 17 (or more) different subclasses. ${ }^{20}$ Two of the most abundant NEA Stony subclasses are the S-type ordinary chondrites and the C-type carbonaceous chondrites. The S-type contains metal (primarily iron-nickel) and high levels of distinguishable minerals. The C-type contains highly oxidized metals (little or no free metal) and abundant volatiles (up to 20 percent bound water and 6 percent organic material).

Due to the uncertainty in asteroid physical, mineral, and volatile characteristics, the primary requirement for early robotic and human asteroid missions is to prospect the asteroid resources and obtain engineering data that can be used to correct and optimize the design of future asteroid material excavation, transfer, and processing capabilities. The NASA Asteroid Redirect Mission (ARM) is currently evaluating mission concepts for capturing and moving NEAs from 3 to 10 meters in diameter or a boulder on a larger NEA depending on the density of the asteroid selected. Sample acquisition and excavation hardware should be designed for a minimum of 1 meter penetration depth to as much as 5 meters. 
As was the case at the start of the Constellation program, ISRU developers and mission planners are using studies to identify what resources and products from S and C-type asteroids might be beneficial for near term missions or enabling for long-term sustainable human exploration of the moon and Mars. It is theorized that like lunar and Mars exploration, mining water and other volatiles (carbon monoxide/dioxide, hydrocarbons, organics) for life support and radiation, shielding, and production of propellants and fuel cell reactants for space transportation and power will be important at scales and production rates similar to those studied for lunar and Mars surface missions. Besides water, use of the bulk material or metals extracted from asteroid material might be important for building structures, parts, and radiation shields.

\section{Processing Technology}

Technology is defined as the practical application of scientific knowledge to solve problems or invent useful tools. Although the line between capability goals and technology requirements is often blurred, in the previous section the capability goals to accomplish the missions were discussed: how much oxygen propellant is needed for the ascent vehicle, how much for life support, how much regolith needs to be moved for landing pads or radiation shielding, etc. In this section and the next, technology solutions and requirements for system components that will enable the needed capability are discussed.

While it is natural to consider ISRU technology needs in a chronological operational order, for example resource acquisition and then processing, the assumptions and efficiencies involved with the processing options will affect the acquisition requirements. Therefore processing technologies will be discussed first, followed by resource acquisition.

\section{A. Mars Atmosphere Processing}

The baseline Mars mission calls for production of oxygen from the carbon dioxide in the Mars atmosphere. A leading option is to electrolyze the carbon dioxide in a solid oxide electrolysis unit at temperatures around $800 \mathrm{C}$, resulting in high purity oxygen at one outlet and a mixture of carbon monoxide and un-reduced carbon dioxide on the other outlet:

$$
\mathrm{CO}_{2} \rightarrow a \mathrm{O}_{2}+b \mathrm{CO}+c \mathrm{CO}_{2}
$$

While reaction (1) can theoretically go to completion to extract one oxygen atom from every $\mathrm{CO}_{2}$ molecule $(\mathrm{a}=1 / 2, \mathrm{~b}$ $=1, \mathrm{c}=0$ ), in reality the voltage required to drive the reaction all the way to the right results in degradation of the solid oxide cell, causing it to give up its own oxygen atoms. Current technology typically operates at approximately 50 percent reduction of the $\mathrm{CO}_{2}(\mathrm{a}=1 / 4, \mathrm{~b}=\mathrm{c}=1 / 2)$. The remaining $\mathrm{CO}_{2}$ and $\mathrm{CO}$ can either be vented back to the environment or sent to a second component where the $\mathrm{CO}_{2}$ is separated from the $\mathrm{CO}$ and recycled back into the electrolyzer. Assumptions of 90 percent efficiency of $\mathrm{CO} / \mathrm{CO}_{2}$ separation would result in 95 percent of the $\mathrm{CO}_{2}$ being reduced to $\mathrm{O}_{2}$ and $\mathrm{CO}$.

A second option for producing oxygen is the reverse-water-gas-shift (RWGS) reaction combined with water electrolysis:

$$
\begin{gathered}
\mathrm{CO}_{2}+\mathrm{H}_{2} \rightarrow b \mathrm{CO}+c \mathrm{CO}_{2}+d \mathrm{H}_{2}+e \mathrm{H}_{2} \mathrm{O} \\
\stackrel{e \mathrm{O}_{2} \mathrm{O} \rightarrow a \mathrm{H}_{2}+a \mathrm{O}_{2}}{\rightarrow+b \mathrm{OO}+c \mathrm{CO}_{2}}
\end{gathered}
$$

The catalytic process is most efficient at about $400{ }^{\circ} \mathrm{C}$. Using conventional catalyst beds, the RWGS process only converts about 10 percent of the $\mathrm{CO}_{2}$ in a single pass, so $\mathrm{CO} / \mathrm{CO}_{2}$ separation and recycling of $\mathrm{CO}_{2}$ is again required to minimize the mass and power of the system. Microchannel RWGS reactors have demonstrated $\mathrm{CO}_{2}$ conversion from 40 to over 50 percent with selectivity to carbon monoxide of $>99.99$ percent and with minimal pressure drop. ${ }^{21}$ Assuming a conversion of 50 percent, the net reaction is the same as for the solid oxide electrolysis technology, with the assumption that all of the unreacted $\mathrm{H}_{2}$ and all $\mathrm{H}_{2}$ from water electrolysis can be recycled back into the reactor $(\mathrm{d}$ $+\mathrm{f}=1$ in eqn 2). In addition to a gas separator to separate the $\mathrm{CO}$ from the unconverted $\mathrm{CO}_{2}$ and $\mathrm{H}_{2}$, the RWGS process also requires several additional components: a condenser or other device to separate the water from the $\mathrm{CO}$, $\mathrm{CO}_{2}$, and $\mathrm{H}_{2}$; a water electrolyzer; a dryer to dry the oxygen from the electrolyzer before liquefaction and storage; and a dryer to dry the $\mathrm{H}_{2}$ before recirculation back to the RWGS reactor. Because the hydrogen is continually 
recycled, the total amount of hydrogen required to 'prime' the process is a system-level decision, and may be based on losses expected for the mission duration.

Table IV. $\mathrm{CO}_{2}$ and $\mathrm{H}_{2} \mathrm{O}$ processing requirements for production of $\mathrm{O}_{2}$ from Mars atmosphere for human mission.

\begin{tabular}{|c|c|c|c|c|c|}
\hline all numbers in $\mathrm{kg} / \mathrm{hr}$ & $\begin{array}{c}\text { w/out } \\
\text { recycling }\end{array}$ & $\begin{array}{c}\text { with } \\
\text { recycling }\end{array}$ & $\begin{array}{c}\text { w/out } \\
\text { recycling }\end{array}$ & $\begin{array}{c}\text { with } \\
\text { recycling }\end{array}$ & \\
\hline Primary reactor & SOE & SOE & RWGS & RWGS & IL \\
\hline $\begin{array}{l}\text { Inlet gases } \\
\mathrm{CO}_{2} \\
\mathrm{H}_{2}\end{array}$ & 12.1 & 12.1 & $\begin{array}{l}12.1 \\
0.55\end{array}$ & $\begin{array}{l}12.1 \\
0.55\end{array}$ & 6.37 \\
\hline $\begin{array}{l}\text { Outlet gases } \\
\mathrm{O}_{2} \\
\mathrm{H}_{2} \mathrm{O} \\
\mathrm{CO}_{2} \\
\mathrm{CO}\end{array}$ & $\begin{array}{r}2.2 \\
6.05 \\
3.85\end{array}$ & $\begin{array}{l}6.05 \\
3.85\end{array}$ & $\begin{array}{r}2.48 \\
6.05 \\
3.85\end{array}$ & $\begin{array}{r}2.48 \\
6.05 \\
3.85\end{array}$ & $\begin{array}{l}0.32 \\
3.85\end{array}$ \\
\hline $\begin{array}{l}\text { CO/ } / \mathrm{CO}_{2} \text { Separato } \\
\text { Inlet gases } \\
\mathrm{CO}_{2} \\
\mathrm{CO}\end{array}$ & & $\begin{array}{l}6.05 \\
3.85\end{array}$ & & $\begin{array}{l}6.05 \\
3.85\end{array}$ & \\
\hline $\begin{array}{l}\text { Outlet gases (back to primary } \\
\text { reactor) } \\
\mathrm{CO}_{2}\end{array}$ & & 5.45 & & 5.45 & \\
\hline $\begin{array}{l}\mathrm{CO}_{2} \text { acquisition summary } \\
\text { Total } \mathrm{CO}_{2} \text { into primary } \\
\text { reactor } \\
\mathrm{CO}_{2} \text { from recycle stream }\end{array}$ & 12.1 & $\begin{array}{r}12.1 \\
5.45 \\
\end{array}$ & 12.1 & $\begin{array}{r}12.1 \\
5.45 \\
\end{array}$ & 6.37 \\
\hline $\mathrm{CO}_{2}$ from atmosphere & 12.1 & 6.65 & 12.1 & 6.65 & 6.37 \\
\hline
\end{tabular}

Use of ionic liquids for separating and extracting oxygen from carbon dioxide is another promising, but much lower technology readiness level, approach to making oxygen from Mars $\mathrm{CO}_{2}$. While the current research focus is on identifying the best ionic liquid formulation for the desired process, laboratoryscale tests have shown some potential to drive reaction (1) nearly all the way to the right $(\mathrm{b}=0.95, \mathrm{c}$ $=0.05){ }^{22}$ Table IV lists gas flowrates for several components in an SOE, RWGS, and ionic liquid system to meet the mission requirements from Table II. Note that while the primary SOE or RWGS reactor operates with identical flows with or without $\mathrm{CO}_{2}$ recycling, the inclusion of a $\mathrm{CO} / \mathrm{CO}_{2}$ separator significantly affects the requirement placed on the Mars atmosphere acquisition system. If the ionic liquid technology can successfully drive reaction (1) to the right, then the Mars atmosphere acquisition requirements would be similar to those for SOE or RWGS with recycling.

If a consumable source of hydrogen is brought from Earth, then the Sabatier process can be used to produce both oxygen and methane at mass mixture ratio of $2: 1$ :

$$
\begin{gathered}
\mathrm{CO}_{2}+4 \mathrm{H}_{2} \rightarrow \mathrm{CH}_{4}+2 \mathrm{H}_{2} \mathrm{O} \\
\frac{2 \mathrm{H}_{2} \mathrm{O} \rightarrow 2 \mathrm{H}_{2}+\mathrm{O}_{2}}{\mathrm{CO}_{2}+2 \mathrm{H}_{2} \rightarrow \mathrm{CH}_{4}+\mathrm{O}_{2}}
\end{gathered}
$$

While this reaction also does not go to completion, conversions of greater than 95 percent have been demonstrated. ${ }^{23}$ Therefore, the unconverted $\mathrm{CO}_{2}$ and $\mathrm{H}_{2}$ have been left out of the right side of Eq. (3) for simplicity, but they are included in the species flowrates summarized in Table V. To maximize $\mathrm{CO}_{2}$ conversion to $>99$ percent, excess $\mathrm{H}_{2}$ is added to the reactant flow into the Sabatier reactor $\left(5: 1 \mathrm{H}_{2} / \mathrm{CO}_{2}\right.$ molar ratio, greater than the stoichiometric ratio of 4:1). While the excess $\mathrm{H}_{2}$ eliminates the need to separate unreacted $\mathrm{CO}_{2}$, it does require the addition of a $\mathrm{H}_{2} / \mathrm{CH}_{4}$ separator. If water is extracted from the soil, then the hydrogen needed to produce methane in the Sabatier process can be obtained through electrolysis of the water. This will also produce sufficient additional oxygen from the water to raise the mass ratio of $\mathrm{O}_{2}$ to $\mathrm{CH}_{4}$ produced to $4: 1$ :

$$
\begin{gathered}
\mathrm{CO}_{2}+4 \mathrm{H}_{2} \rightarrow \mathrm{CH}_{4}+2 \mathrm{H}_{2} \mathrm{O} \\
\stackrel{4 \mathrm{H}_{2} \mathrm{O} \rightarrow 4 \mathrm{H}_{2}+2 \mathrm{O}_{2}}{\mathrm{CO}_{2}+2 \mathrm{H}_{2} \mathrm{O} \rightarrow \mathrm{CH}_{4}+2 \mathrm{O}_{2}}
\end{gathered}
$$


Note in the second reaction in eqn 4 two moles of $\mathrm{H}_{2} \mathrm{O}$ are obtained from the Sabatier reaction, and 2 moles come from the soil water. For an oxygen/methane ascent engine, optimal mixture ratio is around 3.5:1, so the use of in-situ water in the Sabatier process allows for a more optimal engine performance and/or excess oxygen for life support and EVA use. Flowrates for the reaction set in eqn 4 are also included in Table V.

\section{B. Mars Regolith Processing}

Over the past decade Mars orbital and surface exploration missions have discovered that what was once thought of as a dry planet contains not only water ice at the poles but also water close to the surface over much of the planet. ${ }^{24}$ Orbital data from multiple instruments and orbital missions and surface measurements from Viking, Phoenix, and MSL show that water concentrations range from less than 2 percent by mass at the equator to dirty ice at the poles. The form of water across Mars varies as well from hydrated minerals, to loosely bound water, to perma-frost, to thick ice. Some scientists believe Recurring Slope Lineae found on equator-facing slopes may be water-brine mixtures.

The two most likely sources of water to be harvested on Mars are granular soils with looselybound water and/or water of hydration (between 3 and 8 percent by mass) and perma-frost icy soils that may exist in the mid latitudes. To mine the water resource on Mars, two general approaches have been considered: 1) using a rover to excavate and deliver/remove soil to a stationary soil processor and 2) incorporating both excavation and soil processing on the rover and delivering water to a stationary ISRU processor. The selection of either of the two approaches is a function of the concentration of water in the soil and the mission production rate (Table V). For the Mars DRA 5 study, because low concentrations of water were assumed (3 and 8 percent) and therefore a high throughput of regolith was required, option 1 was utilized. Other recent work has examined the viability of option 2 for icy soils. ${ }^{25}$ In both option 1 and 2 , it is assumed that the soils are heated to above $300{ }^{\circ} \mathrm{C}$ to drive off the water in some type of reactor. Because of the discovery that perchlorate minerals exist in Martian soils (potentially up to 0.8 percent), heating soils above $450{ }^{\circ} \mathrm{C}$ may not be advisable due to the release of hydrogen chloride and hydrogen sulfide byproducts.

\section{Lunar Regolith Processing}

Because the moon lacks a useful atmosphere, all resources must be extracted from the regolith. As with Mars, oxygen has been the primary focus as it provides the largest mass payback for use as propellant and life support. While many processes for extracting the oxygen from the oxides in the regolith have been studied, only a few will be discussed here as representative of the range of yield possible, and therefore as indicators of requirements for the amount of regolith to be processed.

Hydrogen reduction uses hydrogen gas to extract oxygen from iron-bearing minerals in the lunar regolith at temperatures greater than $900{ }^{\circ} \mathrm{C}$. Ilmenite, a major component of mare basalts, is the most easily-reduced phase in lunar soil, and can yield almost all of its oxygen (10.5 percent of pure ilmenite) in this process. However, even with reduction of other iron-bearing minerals such as olivine and pyroxene, the maximum yield demonstrated in the lab is 2 to 4 percent (oxygen mass to bulk regolith mass) for high-iron content mare soils; yields of 1 to 2 percent are predicted for low-iron highlands soils. ${ }^{26}$ Even with this low yield, the comparatively low temperature which allows the regolith to remain granular for easier disposal makes the hydrogen-reduction process a leading candidate. Because the oxygen is extracted in the form of water, additional components are needed downstream of the reactor to filter/remove dirt out of the product stream, clean the water of potential caustic impurities, electrolyze the water, and recycle the hydrogen back to the reactor. In addition, the very low yield results in the highest regolith excavation and delivery requirements of all the lunar processes being developed.

Carbothermal reduction uses carbon to extract oxygen from various metal oxides in the lunar soil in a three-step process: 1) reduction of metallic oxides with a carbon source (typically methane) to form carbon monoxide and hydrogen (from the methane source), 2) reduction of carbon monoxide and hydrogen in a methanation reactor to

8

American Institute of Aeronautics and Astronautics 
form methane and water, and 3) electrolysis of the water to form oxygen and hydrogen for recycling back into the carbothermal reactor. Because the carbon will react with most of the metal oxides, the potential yield is much greater than the hydrogen reduction process that only targets the iron-oxides, but the higher temperature $\left(>1350{ }^{\circ} \mathrm{C}\right)$ required for the carbon to dissolve into molten regolith creates new challenges in insulation, management and control of solid carbon formation, and removal of processed regolith (now in solid form). Recent experimental work has demonstrated a system that achieved 15 to 20 percent oxygen yield from lunar simulant. ${ }^{27}$

Molten oxide electrolysis uses direct electrolysis of the metallic oxides in the molten state to extract oxygen without the need for a secondary working fluid or additional components to electrolyze water and/or recycle the working fluids. While this process has the potential to extract all of the oxygen from the regolith for a yield approaching 40 percent, the temperatures of greater than $1650{ }^{\circ} \mathrm{C}$ required to maintain the resulting metals in the liquid phase creates challenges in reactor and electrode materials, reactor insulation, and methods to continually add fresh regolith and extract liquid metals while maintaining thermal balances. This process is still at a low technology readiness level with analytical models guiding very fundamental laboratory tests. ${ }^{28}$

Ionic liquids use acidic ionic liquids to dissolve the regolith and extract the oxygen in the form of water. As with the molten oxide electrolysis technology, ionic liquids have the potential to extract nearly all of the oxygen present in the regolith, and the remaining metals can be gathered at the cathode for further use in manufacturing. The key benefit of the ionic liquids option is the operating temperature of around $200{ }^{\circ} \mathrm{C}$, significantly lower than all other processes being developed. Basic laboratory tests have demonstrated 80 percent recovery of the available oxygen from lunar simulants. ${ }^{29,30}$ Table VI summarizes the amount of lunar regolith that needs to be delivered to the production plant for the various processing options discussed above. While some of the quantities may seem large, the actual excavation area per year is relatively small, ranging from less than 1.5 football fields per year to less than the area covered by the team logo in the center of the field, all assuming an excavation depth of only $5 \mathrm{~cm}$.

Table VI. Lunar regolith acquisition requirements for production of oxygen.

\begin{tabular}{|l|c|c|c|c|c|}
\cline { 3 - 6 } \multicolumn{1}{c|}{} & \multicolumn{4}{c|}{ Regolith Acquisition Rate, kg/day } \\
\hline Processing Method & $\begin{array}{c}\text { Expected } \\
\text { Yield, \% }\end{array}$ & $\begin{array}{c}\text { Early Outpost } \\
\text { Mission }\end{array}$ & $\begin{array}{c}\text { Common area analogy } \\
\text { (based on American } \\
\text { Football field)* }\end{array}$ & $\begin{array}{c}\text { Full Scale } \\
\text { Mission }\end{array}$ & $\begin{array}{c}\text { Common area analogy } \\
\text { (based on American } \\
\text { Football field)* }\end{array}$ \\
\hline $\begin{array}{c}\text { Hydrogen reduction } \\
\begin{array}{c}\text { Highland } \\
\text { Mare }\end{array}\end{array}$ & 2 & 200 & $\begin{array}{c}\sim 1.5 \text { end zones } / \mathrm{yr} \\
<1 \text { end zone } / \mathrm{yr}\end{array}$ & $\begin{array}{c}2,000 \\
1,000\end{array}$ & $\begin{array}{c}\sim 1.5 \mathrm{football} \mathrm{fields} / \mathrm{yr} \\
<1 \mathrm{football} \mathrm{field} / \mathrm{yr}\end{array}$ \\
\hline Carbothermal reduction & 20 & 20 & $\sim 1$ center field logo $/ \mathrm{yr}$ & 200 & $\sim 1.5 \mathrm{end} \mathrm{zones} / \mathrm{yr}$ \\
\hline $\begin{array}{l}\text { Molten oxide electrolysis } \\
\text { or ionic liquids }\end{array}$ & 40 & 10 & $\sim 1$ center field logo / $2 \mathrm{yrs}$ & 100 & $<1 \mathrm{end} \mathrm{zone} \mathrm{/} \mathrm{yr}$ \\
\hline
\end{tabular}

*assuming a $5 \mathrm{~cm}$ excavation depth

Production of solid feedstock for mechanical repairs and spare parts is far longer term than production of consumables for life support, power, and propellants, but is feasible considering recent development of additive manufacturing processes. Manufacturing spares, replacements, tools, and structures in space requires feedstock to produce the desired components and an additive manufacturing capability compatible with the lunar environment and available feedstock. One strategy is to repurpose discarded parts and reconfigure or recycle discarded components into new feedstock that can be used directly by the additive manufacturing system. This will require additional hardware and capability for recycling useable materials back into new components, but results in refined materials with reliable engineering properties. An alternative is to create feedstock from raw materials obtained on the lunar surface. Metal vapor condensate is a by-product of the processes discussed above for extracting oxygen from regolith; the metal vapor condensate may be reformed into feedstock for additive manufacturing, but will have low yield and mediocre mechanical properties which may or may not be adequate for the intended purpose because of the limited metallic elements available in the lunar regolith (primarily iron, calcium, aluminum, magnesium and titanium). The processes that produce the highest oxygen yield will also produce higher-purity/quality metal vapor condensate. In-situ manufacturing with feedstock obtained or derived from resources in space will most likely evolve over time from crude and/or non-mission critical items to more refined products as the experience and hardware to extract and produce high-quality metal feedstock evolves.

\section{Asteroid Processing}

Because of the varied nature of asteroid materials, asteroid processing will incorporate aspects of either/both lunar and Mars processing. The primary difference between asteroid and moon/Mars regolith and soil processing concepts is the lack of gravity, which will require significant modifications to processes developed for the moon or 
Mars. For S-type asteroids that have free metals or low oxide minerals, processing techniques to extract oxygen, metals, and silicon will be very similar to lunar processing techniques previously discussed, with the exception of the carbonyl process to extract free metal nickel-iron deposits or the chemical vapor metal refining process for extracting platinum group metals. For C-type asteroids that have significant concentrations of volatiles such as water, hydrocarbons, and organics, asteroid processing will be similar to those used to extract lunar polar water/volatiles and water from Mars soils, as well as the water condensation, cleanup, and electrolysis processes used to produce oxygen and hydrogen. Because carbon monoxide/dioxide and hydrocarbons may also exist, Sabatier reactors may also be used to make methane fuel.

\section{Resource Acquisition Technology}

As discussed in the previous section, there are two basic types of resources: atmosphere and regolith. The processing methods and efficiencies set the requirements for how much resource is needed.

\section{A. Mars Atmosphere Acquisition}

All of the atmosphere processing methods discussed in Section III require that the Martian 'air' be delivered at a sufficient pressure to overcome pressure drops through the flow system and to enable reasonable volumes for the reactors and other components. This atmosphere acquisition and compression system typically consists of a blower to keep the air flowing, a filter to remove harmful dust particles suspended in the air, and a method to extract the $\mathrm{CO}_{2}$ from the other gases and compress it before delivery to the processing system.

All Mars atmosphere acquisition systems will require dust filtering to protect blower blades, seals, bearings, and valves. The dust in the Mars atmosphere predominantly falls between a radius of 0.05 and 10 microns. ${ }^{31}$ The weighted mean radius of particles gathered from instruments on the Spirit and Opportunity rovers is approximately 1.5 microns. ${ }^{32}$ Number density varies considerably with location and season with an average of 2 particles $/ \mathrm{cm}^{3}$ in standard conditions and 1500 particles $/ \mathrm{cm}^{3}$ during dust storms. ${ }^{31}$ Table VII summarizes the dust environment and temperature and pressure ranges taken from 800 sols of data from the Rover Environmental Monitoring Station

Table VII. Mars production plant component requirements derived from production capability goals.

\begin{tabular}{|c|c|c|c|}
\hline \multicolumn{4}{|c|}{ Mars Atmosphere Conditions (vary with season and day/night cycle) } \\
\hline $\begin{array}{l}\text { Dust, suspended } \\
\text { size range, radius } \\
\text { weighted mean redius } \\
\text { number density, standard conditions } \\
\text { Temperature } \\
\text { Day } \\
\text { Night } \\
\text { Pressure }\end{array}$ & $\begin{array}{l}0.05-10 \text { microns } \\
\sim 1.5 \text { microns } \\
\sim 2 \text { particles } / \mathrm{cm}^{3} \\
-30 \text { to }+5^{\circ} \mathrm{C} \\
-90 \text { to }-60^{\circ} \mathrm{C} \\
730-925 \mathrm{~Pa}\end{array}$ & $\begin{array}{l}800 \text { sol data from MSL Rover } \\
\text { Environmental Monitoring Station }\end{array}$ & $\begin{array}{l}\text { Ref. } 31 \\
\text { Ref. } 32 \\
\text { Ref. } 31\end{array}$ \\
\hline Component & Requirement & Comments & Reference \\
\hline Dust filters & & & \\
\hline $\begin{array}{l}\text { Dust, ISRU systems } \\
\text { Erosion (blades, valve seats, etc.) } \\
\text { Bearings, seals } \\
\text { Dust, human health } \\
\text { Pressure drop }\end{array}$ & $\begin{array}{l}\text { needs more study } \\
\text { needs more study } \\
0.1-10 \text { micron: }<0.05 \mathrm{mg} / \mathrm{m} 3 \\
<300 \mathrm{~Pa}\end{array}$ & 180-day (6-month) exposure limit & Ref. 34 \\
\hline Blower & & & \\
\hline $\begin{array}{l}\text { Inlet pressure } \\
\text { Pressure rise }\end{array}$ & $\begin{array}{l}430-625 \mathrm{~Pa} \\
>2: 1\end{array}$ & Mars ambient less filter delta $\mathrm{P}$ & \\
\hline CO2 compressor & & & \\
\hline $\begin{array}{l}\text { Inlet pressure } \\
\text { Outlet pressure, to SOE } \\
\text { Outlet pressure, to RWGS or Sabatier }\end{array}$ & $\begin{array}{l}900-1300 \mathrm{~Pa} \\
100 \mathrm{kPa} \\
300 \mathrm{kPa}\end{array}$ & Blower inlet times 2:1 head rise & \\
\hline
\end{tabular}

(REMS) $)^{33}$ currently on the Curiosity rover on Mars. With the average atmospheric pressure of Mars around $800 \mathrm{~Pa}$, any filtering device must be able to handle very low-density flow and create minimal pressure drop while removing particles harmful to ISRU components and human health. ${ }^{34}$ Table VII contains initial requirement targets for filtering of the Mars atmosphere at the inlet of the acquisition system.

10

American Institute of Aeronautics and Astronautics 
To keep fresh air supplied to the acquisition system and to recover the pressure drop from the filter unit, some type of blower is required. While positive-displacement blowers are efficient for small demonstrations, they do not scale well to the full requirements of the human exploration mission. Multistage axial blowers are very efficient at both the sample return and human mission scales. Number of stages, tip span, and motor speed can all be varied to develop a long-life design.

The pressure requirement for the $\mathrm{CO}_{2}$ supply gas is dependent on the selected oxygen production method. The solid oxide electrolyzer prefers modest pressures around one Earth atmosphere, or about $100 \mathrm{kPa}$, to reduce the stress on the hot seals. The catalytic reactors in the RWGS and Sabatier options exhibit improved performance at modestly higher operating pressures of around three atmospheres, or $300 \mathrm{kPa}$. In addition, if the catalytic-reactions prove to be sensitive to trace gas species in the atmosphere then they may require that high-purity $\mathrm{CO}_{2}$ be supplied.

The highest technology readiness level concept for the acquisition and compression of the carbon dioxide is the cryofreezer concept. ${ }^{35}$ In this concept the air is passed over a cold head that freezes the carbon dioxide while allowing the other gases (predominantly argon and nitrogen) to vent back to the atmosphere. After sufficient $\mathrm{CO}_{2}$ is captured, the collection chamber is sealed and warmed to create a pressurized gas to feed the oxygen extraction system. The current concept of operation for this method is to collect the carbon dioxide during the night, when the ambient temperature is already reduced, and process it into oxygen during the day. One key technology required is a high-efficiency cryocooler with a low ratio of electric power input to thermal lift.

Another acquisition concept with good potential for low mass and power is a rapid cycle sorption pump. ${ }^{21}$ In this concept, a material that preferentially adsorbs carbon dioxide is used to adsorb the $\mathrm{CO}_{2}$ at low temperature and pressure and then release it at higher pressure when heated. The original mission studies envisioned adsorbing for the entire Martian night as with the cryofreezer, but because of the extremely low density of the sorbent material and its ability to adsorb $\mathrm{CO}_{2}$ at only a fraction of its own weight, this concept resulted in a very large system. The rapid cycle sorption pump cycles from cold adsorption to hot desorption every few minutes, enabled by the use of microchannels to greatly reduce the ratio of structural mass to sorbent mass to minimize thermal losses resulting in frequent heating and cooling of large structural mass. Due to the non-linear temperature and pressure adsorption behavior of the existing sorbent materials, a two-stage system would be the most effective, with each stage producing about an order of magnitude increase in pressure. Subscale units have been demonstrated in a relevant environment at about $1 / 1000^{\text {th }}$ scale necessary for human-scale missions. ${ }^{36}$

Ionic liquids can be tailored to selectively adsorb $\mathrm{CO}_{2}$ from a mixed-gas stream, and there is significant research in this area for cleaning up flue gas effluents. ${ }^{37,38}$ Initial promising results in this industry have drawn the attention of the in-situ resources community, who have begun to investigate whether the ionic liquids can be a viable method to extract and compress the $\mathrm{CO}_{2}$ from the atmosphere in a similar temperature-swing sorption/desorption cycle as described above for the rapid cycle sorption pump.

Mechanical compression of the Martian atmosphere has also been considered. In this concept a mechanical compressor is used to raise the pressure all the way up to the required operating pressure. Early studies determined that mechanical compressors would be too heavy and power-intensive to be effective, and this drove the work in the cryofreezing and sorption pump options. ${ }^{23}$ Since then, advances in turbomachinery design, especially the use of magnetic bearings, have the potential to greatly reduce power, and this option should again be evaluated. Unlike the cryofreezer and sorption pump, however, the mechanical compression does not separate out other atmospheric gases, and a separate separation system would be needed for any oxygen extraction process that is sensitive to these gas species. The requirements for Mars atmosphere acquisition systems are summarized in Table VII.

\section{B. Mars Regolith Acquisition}

Following the approach in the DRA 5 study, near-surface water contents of 3 and 8 percent are considered here to determine soil processing requirements. ${ }^{10}$ Assuming that the soil processing system can operate at a 90 percent water-capture efficiency, the total soil processing requirements are listed in Table V to meet the needs of the Sabatier processing option.

Requirements for Mars icy soil acquisition will ultimately depend on water concentration and both horizontal and vertical distribution of the water. More in-situ measurements of Mars icy soils is needed to characterize the full resource potential. Reference 39 contains an extensive review of drilling and excavation tools that have been developed and tested to date for Mars regolith acquisition.

\section{Lunar Regolith Acquisition}

For extraction of oxygen from the lunar regolith, the loose regolith that covers most of the surface must be collected and delivered to the processing plant. While this can be done continuously in small batches to match the processing plant's needs, analysis has shown that the highest energy drain will come from driving back and forth 
from the excavation site, to the plant, to the discard site, and back to the excavation site. Therefore, systems analysis recommends that each day's regolith be gathered and delivered in only a few trips, typically between 2 and 5 depending on total quantity needed. ${ }^{40}$ Total excavation energy minimizes at fewer trips primarily because the total amount of regolith is not as large as expected and therefore the excavation energy for scooping loose regolith is much less than the driving energy. Table VI lists the daily regolith requirements for both the Early Outpost mission and the Full Scale mission discussed in Section IIIA; the table also lists analogies for total daily or yearly areas that need to be excavated assuming a cut depth of only $5 \mathrm{~cm}$ and an average bulk density of $1700 \mathrm{~kg} / \mathrm{m}^{3}$.

Tests of frozen lunar simulants with various moisture content have shown that the unconfined compressive strength (UCS) increases nearly linearly with increasing water content. Regolith excavatability analogies range from very weak coal, to weak shale or mudstone, to moderate-strength limestones, to strong limestone or sandstone. While the lowest water content/strength frozen regolith may be excavated with conventional scoops, the excavation force, and therefore reaction force/mass, required for the higher water contents (and those soils of greater interest) quickly becomes prohibitive for a space-based process. Some type of drilling or cutting tool will be required to loosen the soil before it can be collected and the water harvested. Table VIII lists some representative values of UCS and Earth-analogues for various water contents. ${ }^{41}$

Table VIII. Examples of strength of frozen JSC-1a lunar simulant for
increasing water content.
\begin{tabular}{|c|c|l|}
\hline $\begin{array}{c}\text { Water content, } \\
\text { wt \% }\end{array}$ & $\begin{array}{c}\text { UCS, } \\
\text { MPa }\end{array}$ & \multicolumn{1}{|c|}{ Earth analogue } \\
\hline $0-0.3$ & $1-3.4$ & weak coal \\
$0.6-1.5$ & $6-14$ & weak shales and mudstones \\
$8-9$ & $31-43$ & moderate-strength limestones and sandstones \\
$10-11$ & $70-71$ & strong limestone, sandstone, and high-strength concrete \\
$11.7-11.9$ (sat) & $57-95$ & strong limestone, sandstone, and high-strength concrete \\
\hline
\end{tabular}

\section{Asteroid Resource Acquisition}

Because of the miniscule gravity and the potential variability in asteroid minerals, density, cohesiveness, and crushing strength/friability, significant challenges exist for acquiring, transferring, and eventually dumping asteroid material. Several techniques have been proposed including: augers, pneumatic transport, electrostatic traveling waves, rotating wheels/brushes, and clam-shell devices. The technique chosen will be based on a number of considerations including the ability to anchor to the surface or hold position during excavation (weight on bit), asteroid material density and strength, and especially the asteroid product of interest. Lunar regolith excavation and material experience using augers and pneumatic transfer may be applicable to asteroid material acquisition. ${ }^{42}$

\section{Concluding Remarks}

The concept of sustainable exploration through the utilization of local resources has been gaining momentum recently as NASA pushes to expand human presence beyond low Earth orbit. While some substantial and innovative research has been conducted in technologies for both lunar and Mars ISRU, changing mission parameters and NASA objectives have resulted in a somewhat disjointed effort. Anchored to current NASA mission architectures, this paper is an effort to specify requirements and objectives for the systems and components that will be needed to enable robust and sustainable human exploration.

\section{Acknowledgments}

Much of the requirements listed in this paper have been developed as a result of two roadmap efforts currently underway within NASA. D. Linne is the co-Chair and ISRU lead for Technology Area 7 (TA7) of the NASA Office of Chief Technologist (OCT) Technology Roadmap updates. K. Taminger is the In-situ Manufacturing and Repair lead for the OCT TA7 team. G. Sanders is the ISRU lead for the Systems Maturation Team developing Capability Roadmaps for the NASA Human Exploration and Operations Mission Directorate.

\section{References}

"'The Global Exploration Roadmap," written by the International Space Exploration Coordination Group (ISECG), August, 2013, published by National Aeronautics and Space Administration, NP-2013-06-945-HQ (available from http://www.globalspaceexploration.org).

${ }^{2}$ Sanders, G.B., Larson, W.E., Sacksteder, K.R., and Mclemore, C.A., Simon, T., and Johnson, K., "NASA In-Situ Resource Utilization (ISRU) - Technology and Development Project Overview," presented at the Space Technology Applications International Forum (STAIF), Feb, 2008 (available from http://ntrs.nasa.gov/archive/nasa/casi.ntrs.nasa.gov/20080010672.pdf). 
${ }^{3}$ Fincannon, J., "Lunar South Pole Illumination: Review, Reassessment, and Power System Implications," AIAA 2007-4700, June 2007.

${ }^{4}$ Strahan, A.L., and Johnson, A.E., "Terrain Hazard Detection and Avoidance During the Descent and Landing Phase of the Altair Mission," AIAA 2010-7722, August 2010.

${ }^{5}$ Drake, B.G. (editor), "Human Exploration of Mars Design Reference Architecture 5.0 Addendum," NASA-SP-2009-566ADD, July 2009.

${ }^{6}$ Colaprete, A., et. al., "Detection of Water in the LCROSS Ejecta Plume," Science 330, 463 (2010); DOI: 10.1126/science.1186986.

${ }^{7}$ Freundlich, A., Ignatiev, A., Horton, C., Duke, M., Curreri, P., and Sibille, L., "Manufacture of solar cells on the moon," in the Conference Record of the $31^{\text {st }}$ IEEE Photovoltaic Specialists Conference, 2005.

${ }^{8}$ Drake, B.G. (editor), "Human Exploration of Mars Design Reference Architecture 5.0,” NASA-SP-2009-566, July 2009.

${ }^{9}$ Drake, B.G., "Human Exploration of Mars Design Reference Architecture 5.0, Executive Summary," February 2009 (available from (available from http://ntrs.nasa.gov/archive/nasa/casi.ntrs.nasa.gov/20090012109.pdf).

${ }^{10}$ Sanders, G. B., "In-Situ Resource Utilization on Mars - Update from DRA 5.0 Study," AIAA 2010-799, January 2010.

${ }^{11}$ National Aeronautics and Space Administration. Mission Concept Study: Planetary Science Decadal Survey - Mars 2018 MAX-C Caching Rover, March 2010 (available from http://sites.nationalacademies.org/SSB/SSB_059331. Downloaded April 20, 2012).

${ }^{12}$ National Aeronautics and Space Administration. Mission Concept Study: Planetary Science Decadal Survey - MSR Orbiter Mission (including Mars Returned Sample Handling), March 2010 (available from http://sites.nationalacademies.org/SSB/SSB_059331. Downloaded April 20, 2012).

${ }^{13}$ National Aeronautics and Space Administration. Mission Concept Study: Planetary Science Decadal Survey - MSR Lander Mission, March 2010 (available from http://sites.nationalacademies.org/SSB/SSB_059331. Downloaded April 20, 2012).

${ }^{14}$ Sridhar, K.R., "Mars Sample Return Mission with In-Situ Resource Utilization,” JPP, Vol 11, No 6, Nov-Dec 1995.

${ }^{15}$ Callaway, U., Merritt, G., Parker, M., Turner, J., Peck, M., Harris, B., Wong, N., and Oltman, J., “An Unmanned Mission to Mars with Sample Return and In-Situ Resource Utilization,” NASA-CR-197202, May 1994.

${ }^{16}$ Zubrin, R., and Price, S., "Low Cost Mars Sample Return with In-Situ Propellant Production," NASA-CR-188371 (contract NAS 9-19359), March 1995

${ }^{17}$ Bruckner, A.P., Nill, L., Schubert, H., Thill, B., and Warwick, R., "Mars Rover Sample Return Mission Utilizing In Situ Production of the Return Propellants," AIAA 93-2242, June 1993.

${ }^{18}$ Gonzales, A., Stoker, C., Lemke, L., and Bowles, J., "Mars Sample Return Possibilities," Ver 4.0, presentation dated February 7, 2013.

${ }^{19}$ Brophy, J.R., Friedman, L., et. al., "Returning an Entire Near-Earth Asteroid in Support of Human Exploration Beyond Low-Earth Orbit,” GLEX-2012.11.1.7x12334, May 2012 (available from http://hdl.handle.net/2014/42734).

${ }^{20}$ Leis, J., Matthews, M., and Gurrieri, M., ”Asteroidal Resource Opportunities Suggested by Meteorite Data," Resources of Near-Earth Space, University of Arizona Press, 1993, pg 523-542.

${ }^{21}$ Brooks, K.P., Caldwell, D.D., Holladay, J.D., Howard, C.L., Hu, J., Kee, R.J., Lilley, B.P., Rassat, S.D., Romig, K.A., Schlahta, S.N., Simon, T.M., and Zhu, H., "Microchannel In Situ Propellant Production System Project Final Report," BattellePacific Northwest Division Rept. PNWD-3670, Richmond, WA, March 2006.

${ }^{22}$ Rosen, B.A., Salehi-Khojin, A., Thorson, M.R., Zhu, W., Whipple, D.T., Kenis, P.J.A., and Masel, R.I., "Ionic LiquidMediated Selective Conversion of $\mathrm{CO}_{2}$ to $\mathrm{CO}$ at Low Overpotentials," Science 334, 643 (2011); DOI: 10.1126/science.1209786.

${ }^{23}$ Zubrin, R.M., Muscatello, A.C., and Berggren, M., "Integrated Mars In Situ Propellant Production System," J. Aero Eng, Jan. 2013.

${ }^{24}$ Beaty, D., et. al, "Potential Water Resource Deposits on Mars: Location and Spatial Relationships to Regions of High Interest for Astrobiology and Safe Spacecraft Operations," Space Resources Roundtable, June 2012.

${ }^{25}$ Zacny, K., Chu, G., Avanesyan, A., Craft, J., and Osborne, L., "Mobile In-Situ Water Extractor (MISWE) for Mars, Moon, and Asteroids In Situ Resource Utilization," AIAA 2012-5168, September 2012.

${ }^{26}$ McKay, D.S., and Allen, C.C., "Hydrogen Reduction of Lunar Materials for Oxygen Extraction on the Moon," AIAA 960488, January 1996.

${ }^{27}$ Gustafson, R.J., White, B.C., and Fidler, M.J., “Analog Field Testing of the Carbothermal Regolith Reduction Processing System," AIAA 2010-8901, September 2010.

${ }^{28}$ Sibille, L., and Dominguez, J.A., "Joule-heated Molten Regolith Electrolysis Reactor Concepts for Oxygen and Metals Production on the Moon and Mars," AIAA 2012-0639.

${ }^{29}$ Karr, L.J., Paley, M.S., Marone, M.J., Kaukler, W.F., and Curreri, P.A., "Metals and Oxygen Mining From Meteorites, Asteroids and Planets Using Reusable Ionic Liquids," 2012 Pisces Conference Abstracts, November 2012 (available from http://ntrs.nasa.gov/archive/nasa/casi.ntrs.nasa.gov/20130001681.pdf).

${ }^{30}$ Karr, L.J., Paley, M.S., Marone, M.J., Kaukler, W.F., and Curreri, P.A., "Metals and Oxygen Mining From Meteorites, Asteroids and Planets Using Reusable Ionic Liquids," presented at 2012 Pisces Conference Abstracts, November 2012 (available from http://ntrs.nasa.gov/archive/nasa/casi.ntrs.nasa.gov/20130001749.pdf).

${ }^{31}$ Chicarro, A., Colangeli, L., Vago, J., and Witasse, O., "The Role of Dust in the Martian Climate," presented at the Workshop on Dust and Grains in Low Gravity and Space Environment, April 20012 (available from http://congrexprojects.com/docs/11m24_docs/02apr_1630_chicarro.pdf?sfvrsn=2). 
${ }^{32}$ Lemmon, M.T., et. al., "Atmospheric Imaging Results from the Mars Exploration Rovers: Spirit and Opportunity," Science Vol. 306, December 2004.

${ }^{33}$ Rover Environmental Monitoring Station (REMS) website: cab.inta-csic.es/rems/marsweather.html\#slide-to-main, accessed December 2, 2014.

${ }^{34}$ Constellation Program Human-Systems Integration Requirements, CxP 70024, Revision E, released November 19, 2010 (available from http://ntrs.nasa.gov/archive/nasa/casi.ntrs.nasa.gov/20120014522.pdf).

${ }^{35}$ Clark, D.L., Payne, K.S., and Trevathan, J.R., "Carbon Dioxide Collection and Purification System for Mars," AIAA 20014660, August 2001.

${ }^{36}$ Linne, D.L., Gaier, J.R., Zoeckler, J.G., Kolacz, J.S., Wegeng, R.S., Rassat, S.D., and Clark, D.L., "Demonstration of Critical Systems for Propellant Production on Mars for Science and Exploration Missions," AIAA 2013-0587.

${ }^{37}$ Gurkan, B., et. al., "Molecular Design of High Capacity, Low Viscosity, Chemically Tunable Ionic Liquids for CO2 Capture," J. Phys. Chem. Lett. 2010, 1, 3494-3499, DOI: 10.1021/jz101533k.

${ }^{38}$ Zhang, J., Sun, J., Zhang, X., Zhao, Y., Zhang, S., "The Recent Development of $\mathrm{CO}_{2}$ Fixation and Conversion by Ionic Liquid," Greenhouse Gas Sci Technol. 1:142-159 (2011); DOI: 10.1002/ghg13.

${ }^{39}$ Bar-Cohen, Y., and Zacny, K. (ed.), Drilling in Extreme Environments, Wiley-VCH Verlag GmbH \& Co. KGaA, Weinheim, 2009, Chap. 6 (ISBN: 978-3-527-40852-8).

${ }^{40}$ Linne, D., Gallo, C., and Joseph, A., "Preliminary Trade Study on Scoop Size for Large Excavation Vehicle," presented at Planetary and Terrestrial Mining and Sciences Symposium (PTMSS), June 2009 (available from http://www.deltion.ca/ptmss/members.php).

${ }^{41}$ Gertsch, L., Rostami, J., and Gustafson, R., "Review of Lunar Regolith Properties for Design of Low Power Lunar Excavators," $6^{\text {th }}$ International Conference on Case Histories in Geotechnical Engineering, Paper No. 10.02, August 2008.

${ }^{42}$ Zacny, K., et. al, "Asteroids: Anchoring and Sample Acquisition Approaches in Support of Science, Exploration and In situ Resource Utilization,” Asteroids, 2013, pp 287-343. 